\title{
Entre o mar e o rochedo: uma análise antropológica sobre as noções de natureza em Os trabalhadores do Mar de Victor Hugo ${ }^{1}$
}

\author{
Marta Cioccari
}

resumo A partir da noção de natureza, analiso neste artigo o universo do escritor francês Victor Hugo, examinando como suas concepçôes - marcadas pelos valores românticos do século XIX - ganham corpo e densidade na obra Os trabalhadores do mar. Nesta obra, acerca da epopeia do homem contra a Natureza, seguimos a trajetória de Gilliatt: um pescador que náo apenas encarna os valores de seu criador como simboliza a saga dos indivíduos das classes populares, vistos como dignos apenas pela via do sacrifício e do heroísmo. Adotado como metáfora em sua trama narrativa, o traspassamento de diferentes elementos, humanos e não humanos, no fluxo de imagens tecidas por Hugo sinaliza, a meu ver, uma espécie de devir, no qual as intensidades presentes no imaginário do autor geram surpreendentes multiplicidades.

palavras-chave Antropologia. Literatura. Victor Hugo. Trabalhadores do mar. Natureza.

Sempre que eu ouvia as histórias contadas por Seu Leo, um velho mineiro de carvão, durante minha etnografia de mestrado (Cioccari, 2004) e, depois, de doutorado, em Minas do Leão (RS), era inevitavelmente surpreendida. Certa vez, ao explicar a sua ligação com a mina de subsolo, tecida ao longo de 35 dos seus 78 anos de vida, ele me disse: "O carvão é como o mar, apaixona a gente”. O relato do ex-mineiro continha não apenas a magia dos subterrâneos, mas também a descrição das tragédias a que assistiu e a contabilidade dos companheiros que perdeu. Evidenciava que o engajamento no mundo da mina - como aquele no mar continha seus riscos, sortilégios e armadilhas. Essas imagens passaram a povoar minhas reflexôes acerca do mar e da mina, envolvendo cruzamentos entre a antropologia, o trabalho de campo e a literatura.

Neste ensaio, debruço-me sobre as relaçóes entre o homem e a natureza, tomando como base o romance Os trabalhadores do mar (1866), do escritor francês Victor Hugo. Busco identificar, através da intriga construída pelo autor sobre as aventuras de Gilliatt, os valores de que partilham escritor e suas personagens, vendo-os em consonância com o movimento romântico do século XIX. Nesta abordagem, parto de uma concepção contemporânea em torno do conceito de natureza, vendo-o como uma construção social e cultural, como sugerem Philippe Descola (1996) e Roy F. Ellen (1996), e considerando a própria definição de Victor Hugo sobre a transnatureza, assim como as interpenetraçóes possíveis de sentidos entre humanos e não humanos a partir da noção de devir de Deleuze \& Guattari (1997). A contextualização do universo de Victor Hugo ancora-se nas análises de Paul Bénichou (1988) e de Henri Focillon (2001), assim como em estudos acerca dos princípios impressos pelo Romantismo na literatura e nas ciências sociais. 
É preciso considerar que, se as grandes imagens ligando o mar à mina estão presentes no imaginário das classes populares, tal presença nada tem de fortuita. Antes, integram a circularidade de ideias que contribuíram para a construção de um modelo heroico na vida dos trabalhadores e que, de tempos em tempos, ressurgem um pouco em cada lugar, alimentadas seja pela ciência, pela literatura, pelo cinema como pelas mídias. No século XIX, tal conexão aparecia explicitamente na obra do engenheiro Louis Simonin (1867), La vie souterraine: les mines et les mineurs, na qual ele destacava a aproximação do universo do marinheiro e do mineiro, citando a (então) recente obra de Victor Hugo:

Aquilo que ele [Hugo] chama táo adequadamente de obstáculo, a ananke dos elementos, se dirige também contra o mineiro. Como o marinheiro, ele é o soldado do abismo, e contra ambos obstina-se fatalmente a natureza (Simonin, 1867, p. I).

A publicação do estudo de Simonin sobre os mineiros, um ano após o lançamento da obra de Hugo sobre os trabalhadores do mar, teria inspirado Émile Zola a escrever Germinal (1885), traduzindo a saga dos mineiros franceses. Com uma diferença: Simonin, ex-engenheiro das minas do Loire, tornou-se o principal ideólogo das companhias carboníferas; Zola, que desce à mina em Denain, Norte da França, em fevereiro de 1884, enfrentando o sentimento aterrador de um mergulho nos "infernos", ao publicar Germinal, aporta uma das maiores contribuiçóes para o imaginário coletivo sobre a vida dos trabalhadores no subsolo - da qual os próprios mineiros se apropriariam para falar de si.

Dando curso à circularidade entre os dois mundos, foi em meio à etnografia com mineiros de carvão que redescobri a obra de Victor Hugo. Depois, o mergulho nesta literatura deu-se numa viagem de descanso, na qual eu desfrutaria dos prazeres da beira-mar. Durante a leitura, mirando o mar que se desenha sobre um horizonte de ilhas, vivia a ambiguidade de, a um só tempo, registrar impressóes muito diferentes sobre a natureza: a do prazer sensorial do corpo exposto ao sol e a da contemplaçáo da paisagem ${ }^{3}$; a do espetáculo sublime da leitura de Victor Hugo, com suas tempestades tão terríveis quanto magníficas, ao mesmo tempo em que olhava para um mar que, a mim, entrevia tanto o acolhimento como a ameaça; e, ainda, a da fruição no ato de leitura, da imersão na obra e em mim mesma, como parte de um self-cultivation simmeliano (Simmel, 1998). Esta leitura provocou, enfim, uma sacudidela existencial similar à vivida muitos anos antes no contato com Germinal, de Zola - ou seja, momentos em que o literário carrega uma força capaz de revirar entranhas do pensamento e de afetar nosso olhar sobre o mundo.

\section{A natureza como construçáo social e cultural}

Pode-se dizer, seguindo Philippe Descola (1996), que as concepçóes de natureza são socialmente construídas e variam segundo as determinações culturais e históricas. Como lembra o autor, nossa própria visão dualista do universo não pode ser projetada como um paradigma ontológico universal, pois há muitas culturas nas quais ele não se aplica. Essas reflexões surgiram tanto pela crítica promovida pela metafísica e pelas epistemologias ocidentais como também resultaram de estudos conduzidos por antropólogos, nos quais a dicotomia natureza-cultura mostrava-se inadequada para dar conta das formas pelas quais os povos estudados interagiam com seu meio físico (Descola, 1996, p.82). Em algumas culturas, por exemplo, as pessoas atribuíam disposições e comportamentos humanos a plantas e animais e expandiam a concepção de organismos não humanos para espíritos, monstros, 
artefatos minerais ou alguma entidade, elementos que surgiam como portadores de consciência, capacidade de comunicação, mortalidade, crescimento, conduta social e código moral. $\mathrm{O}$ dualismo conceitual também foi favorecido pela persistência de oposiçóes binárias entre o natural e o sobrenatural. Em Durkheim, tem-se a ideia da ordem sobrenatural como derivada de uma ordem natural de coisas, formando uma categoria residual para uma totalidade de fenômenos incompatíveis com a racionalidade e as leis do universo. A oposição natureza-sobrenatureza foi então formada dentro de uma racionalização do mundo físico (Descola, 1996, p.83). A posição que o autor adota para fugir a esse dualismo é evitar o uso da categoria de natureza, considerando-a vaga no atual debate antropológico. No entanto, apesar da amplitude e das dificuldades de definição, ela figura nas bases do pensamento antropológico. Daí a razão para considerá-la nesta análise como um ponto de partida, buscando interrogar os sentidos que assume no contexto de Hugo e no desenrolar da trama de seu romance.

Roy Ellen (1996) parte da ideia de que as concepçôes em torno da natureza variam histórica e etnograficamente e são culturais, embora assumam frequentemente o papel de "verdade antropológica autoevidente" (Ellen, 1996, p.103). Segundo Ellen, os estudos históricos e etnográficos têm mostrado a abstração dessa categoria. A seu ver, o consenso origina novos problemas: a incomensurabilidade entre diferentes concepções de natureza; a implicação de que cada cultura tem uma concepção particular da natureza, diante da qual a tarefa do antropólogo é localizar, escavar e descrever; e a existência de noçôes coletivas de cultura que seriam "construídas" ou "negociadas". Em seu estudo, propóe três dimensóes para o uso da categoria natureza. A primeira corresponde a uma objetivação do mundo e à concepção de "natureza como coisa” (como o espaço dos museus); na segunda, há uma objetivação do espaço no qual a natureza aparece "como espaço não humano"; por último, a ideia de interioridade, na qual a natureza é essência, intrínseca ao humano. Neste caso, está fora do controle humano e surge como "natureza humana", podendo dizer respeito a qualidades morais (Ellen, 1996, p.104-112).

\section{Os trabalhadores do mar: a luta contra o Elemento}

No prólogo do romance Os trabalhadores do mar, Victor Hugo (1866) sugere que a religião, a sociedade e a natureza são as três lutas do homem. Essas três lutas são, ao mesmo tempo, suas três necessidades: "precisa crer, daí o tempo; precisa criar, daí a cidade; precisa viver, daí a charrua e o navio". No entanto, há três guerras nessas três soluçóes. Para o autor, o homem tem de lutar com o obstáculo sob a forma superstição, sob a forma preconceito e sob a forma Elemento. "Tríplice ananke (palavra grega que significa necessidade, fatalidade) pesa sobre nós, o ananke dos dogmas, o ananke das leis, o ananke das coisas". Em seus dois romances precedentes, Notre-Dame de Paris e Os miseráveis, ele havia representado, respectivamente, a ananke dos dogmas e das leis. Em Os trabalhadores do mar, decidiu explorar a ananke dos Elementos. A essas três fatalidades que envolvem o homem, segundo o autor, "junta-se a fatalidade interior, o ananke supremo, o coração humano" (Hugo, 1866, p.11). Tais definições deram margem a uma interpretação de que o escritor estava preso a uma concepção fatalista do mundo, visão que foi recebida com desagrado por ele. Dois anos depois do lançamento de Os trabalhadores do mar, Hugo fez uma tentativa de desconstrução desta recepção. No prefácio de L'Homme qui rit, rejeitou a imputação de fatalismo, proclamando que seria preciso ver, no conjunto das suas obras, "uma série de afirmaçôes da alma": a ananke não seria senão permitir à alma, dentro de uma luta 
que é a condição humana, a possibilidade de afirmar seus poderes e sua finalidade.

Em Os trabalhadores do mar, várias passagens nos fazem entrever a impotência do homem diante da fatalidade. Ao descrever, por exemplo, que ao velho marinheiro Lethierry, diante da notícia do naufrágio do barco Durande e da sua ruína financeira, só restava a fé e a oração, Hugo adota uma definição inesperada:

Ser impotente é uma força. Diante das nossas duas grandes cegueiras, o destino e a natureza, é na sua impotência que o homem acha o ponto de apoio, a oração (Hugo, 1866, p.329).

Observa, contudo, que Lethierry não orava. Em outra passagem, dirá:

O homem é o paciente dos acontecimentos. A vida é um perpétuo sucesso, imposto ao homem. O homem não sabe de que lado virá a brusca descida do acaso. As catástrofes e as felicidades entram e saem como personagens inesperadas. Têm a sua fé, a sua órbita, a sua gravitação fora do homem (Hugo, 1866, p. 366).

$\mathrm{Na}$ sua obra, entretanto, o elemento humano, contrariamente ao que poderia sugerir uma leitura superficial, náo está preso a essas circunstâncias. Tais incertezas contêm dentro delas a possibilidade de escolha, de agência humana. É preciso lembrar que a caracterização do herói romântico diz respeito justamente a sua reação frente ao acaso. Ao analisar a construção do caráter do herói na literatura, Bakhtin (1997) opôs duas principais tendências: a construção clássica e a construção romântica. No modelo clássico, a noção de destino é essencial, correspondendo a uma determinação da pessoa marcada por uma necessidade que predetermina todos os acontecimentos da sua vida. $\mathrm{Na}$ construção romântica, encarnada por Hugo, o herói assume a responsabilidade de iniciar a sequência dos atos de sua vida marcada pelos valores e pelo sentido (Bakhtin, 1997).

Um parêntese se faz necessário para melhor situar o contexto do escritor. Victor Hugo, que se tornaria um dos mais importantes representantes do romantismo ${ }^{4}$ na literatura, nasceu em Besançon, na França, em 26 de fevereiro de 1802. Na sua vida e em sua obra, encarnou uma gama vasta de valores românticos, tais como a valorização da natureza e do exotismo, a busca da intensidade da experiência e a concepção do poeta como profeta. Suas paixóes políticas motivariam boa parte de seus escritos - na forma de romances, poesias, dramas, ensaios literários, sátiras e panfletos - e ocasionariam também o seu banimento do país por quase duas décadas. Hugo tinha sido monarquista, mas nutria simpatias por Luiz Napoleão Bonaparte, tendo defendido, em dezembro de 1848, sua candidatura à República francesa. Depois de proclamada a República, Hugo chegou a ser eleito deputado em Paris e carregou como bandeira a luta contra a pena de morte 5 . Sua conversão à esquerda, porém, ocorreria posteriormente, com a desilusão que teve com o governo de Napoleão III. Depois do golpe de Estado de 1851, o escritor, que desde uma década antes era membro da Academia Francesa, viu-se obrigado a sair do país. Viveu algum tempo em Bruxelas, na Bélgica, e depois na ilha de Jersey ${ }^{6}$; em 1855, partiu para a ilha de Guernesey, na Normandia, onde passou 15 dos seus 18 anos de desterro, morando junto ao mar, com a visão do litoral francês ao longe. Este seria o cenário da intriga utilizada por ele em Os trabalhadores do mar (1866), que se passa na ilha de Guernesey, no recife Les Douvres e em Saint-Malo, no continente francês. Nesses anos de exílio, Hugo mergulhou nos hábitos, nos costumes e nas crenças dos camponeses e pescadores da ilha. Era a matéria-prima que usaria para construir o romance, com seu próprio sofrimento de expatriado representando o fermento da criação ${ }^{7}$. O escritor teve uma vida conturbada 
não apenas por questóes políticas, mas também pessoais. Uma tragédia que o marcou profundamente foi a morte por afogamento de sua filha Léopoldine, em 1843. Na vida amorosa, era um homem dividido: paralelamente a seu casamento com Adèle, Hugo teve uma ligaçáo de 50 anos com Juliette Drouet, a amante. Em 1870, ao ser comunicado da queda de Napoleão e da restauração da República, Hugo regressou à capital francesa. Voltaria a envolver-se com causas políticas, elegendo-se senador em $1876^{8}$.

As cicatrizes do desterro marcaram profundamente sua obra, tal como uma revolução em seu interior e em sua experiência poética. "O exílio foi, na história de Hugo, o lugar do sacerdócio [poético] plenamente assumido, um zênite de força e de verdade" (Bénichou, 1988, p.337). Depois de voltar à França, continuou a se considerar voluntariamente "banido", retirando desta condição uma nova definição de si mesmo. A partir daí, conceberia o poeta como um "vingador". Na concepção do romantismo realista, encarnada por ele, o poeta tinha o dom e o dever de apaziguar os tormentos do povo, tal como um "civilizador" (ver Benichot, 1988, p. 306). Toda a obra romanesca produzida a partir do exílio - como Os miseráveis (1862) e Os trabalhadores do mar (1866) - poderia ser considerada como uma contribuição à fábula moderna. A matéria-prima da qual ele parte se expressa em significaçóes e em valores: em Os trabalhadores do mar, por exemplo, encontramos o trabalho sobre-humano, o amor e o sacrifício de si. É importante considerar que este romance é concebido no contexto do surgimento da Associação Internacional dos Trabalhadores, criada em 1864, em Genebra, e um ano antes do primeiro livro de $O$ capital, de Marx, como notou David Charles (2002; 2005). Entre Os miseráveis e Os trabalhadores do mar, observava este autor, Hugo deslocou-se do tema da miséria para o do trabalho, como sugeria o próprio advento da revolução indus- trial: no mundo do trabalho expresso no romance, a miséria continuaria presente, mas sem a consciência dela mesma (cf. Charles, 2005).

$\mathrm{Na}$ arte de Hugo, forma e conteúdo eram indissociáveis, ambos vinham das entranhas do pensamento. Esse aspecto transparece na análise que Henri Focillon (2001) faz da sua obra, no ensaio Elogio da mão, na qual considera que, como Hugo, "não há outro espírito tão rico em espetáculos interiores, em contrastes fulgentes, em erupçóes verbais que descrevem o objeto com uma justeza impressionante”. A seu ver, o escritor "era inspirado como um feiticeiro", coisa que, aliás, o próprio Hugo pensava de si mesmo. Em Os trabalhadores do mar, um dos seus "estranhos romances", Focillon observa que o autor respira,

com a poesia da luta contra as forças elementares, a insaciável curiosidade por saber como se fazem as coisas, se manejam as ferramentas, quais são os seus recursos, o seu comportamento, os seus nomes arcaicos e desconcertantes (Focillon, 2001, p.124).

Nas suas palavras, trata-se de um livro escrito pela mão de um marinheiro, carpinteiro e ferreiro, que se apodera da forma do objeto e o modela, moldando-se também a ele. A felicidade de tal descrição nos remete às condiçōes contidas na noção de "cultura subjetiva" em Simmel (1998), relativas ao desenvolvimento e ao cultivo de si - que o filósofo, ele próprio um dos maiores expoentes do romantismo alemão, tratará como Bildung. Focillon analisa que, na obra de Hugo, até a vaga e o vento têm peso.

E é na medida em que esta sensibilidade extraordinária está à altura da dureza das coisas, dos problemas criados pela inércia, que aceita táo bem a epopeia dos fluidos, os dramas da luz e pinta-os com uma força quase compacta (Focillon, 2001, p.124). 
A intensidade da experiência vivida por Hugo remete-o a considerar a literatura como uma missão - ora gloriosa, ora cruel -, tornando essa concepção elemento do seu ser moral. Essa experiência profunda "obriga-o a viver junto e para a massa à qual fala", como acentuou Bénichou (1988). O escritor afirmava dentro de si a existência de um ser de comunicação, que era ao mesmo tempo seu ser íntimo e privado e, ao mesmo tempo, um personagem que lhe transcendia. Nesta percepção, há uma diferença significativa da ideia clássica, de uma identidade universal na natureza humana, como afirmava Montaigne. No caso de Hugo, não se trata de uma natureza humana, "mas de ensinamento e de salvação” (Bénichou, 1988, p.314). Tanto na poesia como na prosa, Hugo celebrou constantemente uma plenitude da comunicação com a natureza. Um dos aspectos do romantismo que o marcam é o da ambiguidade humana face ao universo natural: ora há uma comunicação plena, ora um sentimento de ansiedade derivado do mutismo da natureza 9 . Como analisou Corbin (1989), um velho axioma da teologia e da ciência medieval afirmava que "a natureza é o livro de Deus", de forma que Ele teria depositado entre os segredos do mundo natural os símbolos destinados ao ensinamento dos homens. Essa concepção, retomada sob diversas formas, durante e após o Renascimento, emerge no século XVIII com o Iluminismo e vem a tornar-se uma das obsessóes românticas ${ }^{10}$. A ideia da natureza como um livro metafórico aparece constantemente na prosa de Hugo. Se, por vezes, o escritor orgulha-se de que o "Livro da Natureza” lhe seja claramente visível, em outras, lamenta não encontrar as respostas que procurava. A natureza parece pronta a falar, mas não elucida a obscuridade que envolve o mundo e o homem. Numa passagem de Os trabalhadores do mar, Hugo fala pela voz de um passageiro do barco Durande: "Deus está ausente. Devia-se lavrar um decreto para obrigá-lo a residir aqui.
Anda lá na sua casa de campo e não se importa conosco [...]." (Hugo, 1866, p.173). Este Deus "escondido" ensina liçóes carregadas de mistérios, gerando mais angústia do que fé.

$\mathrm{Na}$ concepção de Hugo, todas as partes da natureza, ao olhar dos espíritos pensantes, ligam-se entre si por uma multiplicidade de harmonias secretas. Há, no seu pensamento, uma ideia positiva da unidade do mundo - poderíamos dizer de totalidade, que marca a alma dos românticos - verificada pelo parentesco das formas. Em 1837, Hugo escreve:

O vegetal torna-se animal sem que se tenha rompido um só anel na cadeia ${ }^{11}$ que começa na pedra, na qual o homem é o meio misterioso, e na qual os últimos elos da cadeia, invisíveis e impalpáveis para nós, remontam até Deus (Hugo apud Bénichou, 1988, p.322).

Vinte anos depois, voltou a afirmar que o universo "é esta sinonímia”. Nesta unidade da criação, poderiam ser encontradas correspondências entre o físico e o espiritual. Em Hugo, sobressaem mais os contrastes. Para o escritor, Deus trabalha "por antíteses" e pela identidade. Ele escreve, em 1840, que o poeta deveria "fazer como a natureza. Proceder por contrastes". Como a natureza, isto é, como Deus, que é produtor de antíteses. E as antíteses pululam na obra de Hugo. Nessa "imitação" do Criador estão presentes os binômios físico-moral, mal-bem, sombra-luz, que permeiam todo seu universo poético.

$\mathrm{O}$ entusiasmo do escritor pela ciência tinha seus limites. Ele via a ciência como contribuindo para "metamorfosear" o homem em qualquer coisa mais espiritual do que o próprio homem, a lhe fazer ascender na escala dos seres, tornando-se mais distante da brutalidade. Considerava a ciência sob seu aspecto positivo, partindo da ideia de que tal conhecimento seria um meio para melhorar a vida terrestre. Mas seu pensamento pretendia ir além da ci- 
ência. A visão de homem que Hugo sustentará até a sua morte, confrontando-se ao positivismo, implica numa impotência para conhecer o secreto, mas numa capacidade para entrever além do que possibilita a ciência pura. $\mathrm{O}$ escritor considerava que a ciência estuda e conhece a natureza, mas percebia que os valores humanos mais nobres estavam fora do domínio da ciência: estariam assim fora e além da natureza? Essa dualidade aparece em alguns momentos da obra de Hugo. Nos anos 1860, o escritor consagrou dois textos ao sobrenaturalismo Préface philosophique e Contemplation suprême. Estudiosos, como Bénichou (1988), veem ambiguidades neste percurso:

Este rótulo pelo qual ele designa toda a dèmarche do espírito que pretende elevar-se além das ciências da natureza mergulha-o em dificuldades, porque sua religião, ao mesmo tempo em que é uma religiáo do Absoluto, quer ser uma religiấo da Natureza (Bénichou, 1988, p.486).

Para Hugo, a palavra sobrenaturalismo foi inventada por uma ciência oficial e míope, que pretendia rejeitar toda a parte da natureza que náo se encaixa nos dados obtidos pelos sentidos. Por essa razão, o escritor preferia adotar o termo transnatureza a sobrenatureza. De fato, transnatureza parece ser o mais adequado para designar o interpenetrar de limites entre o humano e o não humano - trate-se do ambiente circundante, dos animais, dos seres espirituais, dos vegetais e dos minerais.

A consciência de uma "missão pessoal" fez com que o escritor desenvolvesse, na concepção do universo e da humanidade, uma espécie de "teoria do sacerdócio poético". Essa missão empreendida por ele teria sido desempenhada por outros escritores em outros tempos e seria continuada depois dele. $\mathrm{Na}$ linhagem de uma "confraria secular dos inspirados", como propóe a análise um tanto irônica de Bénichou
(1988) a este respeito, à palavra poeta seria preciso agregar termos como vidente, mago, profeta, derivaçóes que evocam sua familiaridade com o sobrenatural e o sagrado. Mas também sábio, pensador, exercendo a mais alta potência humana e carregando o signo da audácia e da busca incessante, com as quais beneficiaria a humanidade. $\mathrm{Na}$ lista de seus semelhantes, Hugo distingue Shakespeare, Homero, Ésquilo, Rabelais, Dante, Cervantes, entre outros. $\mathrm{Na}$ dimensão espiritual da sua obra há um trio de elementos, constituídos pelo Infinito ou Deus, pela Natureza e pelo Poeta. Trata-se de uma singular sagrada trindade, com um dos vértices ocupado justamente pelo humano criador.

Em Os trabalhadores do mar, encontramos uma formidável combinação de metáforas em torno da ideia de natureza que, exaltando determinados princípios românticos, exibem uma complexa e desconcertante arquitetura que extrapola as definiçóes de natureza como espaço externo e essência humana. Homem e natureza aparecem ora dispostos em combate, ora, por efeito de intrincados jogos de linguagem, misturados numa personificação dos elementos ou em características ou detalhes da natureza - do mar, dos ventos, dos animais, especialmente - que servem para ilustrar traços corporais ou para indicar a personalidade, o caráter e até mesmo a essência, a natureza íntima da personagem. René Journet sugeriu essa mistura de elementos na obra de Hugo, mencionando que, no universo do escritor, "o indivíduo, a sociedade, a natureza e a sobrenatureza, que se confundem em parte, devem ter seu lugar em cada obra" (1988, p.114, grifo meu). Em cada obra, segundo o pesquisador, com um ponto de partida diferente, Hugo recomeça a mesma tentativa de fazer reverberar o problema do Ser.

Ainda que o termo mais usado comumente seja o de sobrenatureza, a noção de transnatureza, preferida pelo escritor, traduz mais claramente a dimensão espiritual e a constante 
transformação das coisas. Quando passamos da substantivação ao dinamismo de uma transnatureza, considerando-a como um movimento contínuo, aproximamo-nos do conceito de devir proposto por Deleuze e Guattari (1997). $\mathrm{Na}$ definição destes autores, todo devir é um movimento criativo que escapa das significaçóes dominantes. Pode-se dizer que o devir afeta o pensamento ao tomar contato com outra perspectiva, gerando textos, poemas, romances, políticas ou mesmo etnografias. "Devir não é certamente imitar, nem identificar-se; nem regredir-progredir, nem corresponder, instaurar relaçôes correspondentes”. Num devir-animal, por exemplo, está-se lidando sempre com uma multiplicidade. Nestas definições, "o eu é apenas um limiar, uma porta, um devir entre duas multiplicidades" (Deleuze; Guattari, 1997, p.33). Os autores observam que

às relações que compóem um indivíduo, que o decompóem ou o modificam, correspondem intensidades que o afetam, aumentando ou diminuindo sua potência de agir, vindo das partes exteriores ou de suas próprias partes (Deleuze; Guattari, 1997, p.42).

Seguindo tal interpretação para ler Hugo, aproximo filosofias distintas, com seus tempos e contextos específicos e sua força explicativa voltada para diferentes fenômenos, mas que partilham não apenas a raiz comum do pensamento romântico como também muitas das noções surgidas nesta perspectiva e que ganharam vigor na contemporaneidade, tais como a da experiência, do fluxo e da intensidade. A proposta de Deleuze e Guattari é avessa às genealogias, preferindo uma geologia das ideias, no sentido de decompor o conhecimento em estratos, camadas ou platôs. Como dizem os autores, escrever talvez não tenha outro objetivo senão o de desencadear devires (Deleuze; Guattari, 1997, p.63). Isso está presente, sem dúvida, no pro- cesso de criação de Victor Hugo. Mas a própria construção deste ensaio também pode ser vista como uma experiência de desterritorialização, ou seja, correspondendo a um deslocamento dos sentidos presentes no ponto de partida do ato de escrita. A saída do território, nos termos dos autores, equivale a improvisar, a ir ao encontro do mundo, convertendo-se num devirmundo (Deleuze; Guattari, 1997, p.117-118). Tal abertura se oferece também na noção de "rizoma" e na possibilidade que abre de ligar um ponto com qualquer outro - já que o rizoma náo é uno nem múltiplo, náo tem começo nem fim, mas é sempre um meio pelo qual cresce e transborda. As multiplicidades são sempre atravessadas por metamorfoses, como explicitaram os autores (Deleuze; Guattari, 1995, p.15-33). Em outra obra, Guattari (2004, p.18) afirmava que, em vez de referências e metáforas cientistas, seria preciso "forjar novos paradigmas que serão, de preferência, de inspiração ético-estética”, sugerindo que as melhores cartografias da psique surgiram na literatura - e não na psicanálise. Uma boa tradução do fenômeno do devir está no exercício de contemplação da paisagem ${ }^{12}$ sugerido por Deleuze e Guattari (1992, p.219), considerando que, neste ato, "tornamo-nos com o mundo" e "nos tornamos". Assim, tornamonos universo por meio dos devires animal, vegetal e molecular. O que teria experimentado Van Gogh, numa das temáticas adotadas pelo artista, não seria outra coisa senão um "devir girassol".

Nesta perspectiva, pode-se pensar que há singulares devires atravessando a trama tecida por Hugo em Os trabalhadores do mar. Pareceme que a própria experiência existencial do autor imprime-lhe essa espécie de devir-natureza, que se desdobra na multiplicidade poética das imagens fantásticas de que lança mão, como o devir-mar, o devir-animal, o devir-mineral, aflorando em abundância e de forma impactante na caracterização de seus personagens. Há, sobretudo, uma recorrência dessa abertura do ser 
que se desdobra para percorrer e experimentar outros universos existenciais. Pode-se considerar, por exemplo, a descrição de Mess Lethierry, apresentado pelo autor como meio-homem, meio-mar, como uma sucessão de devires-natureza que parecem vivificar a sua narrativa para além da adoção de metáforas e recursos figurativos: "voz doce e meiga que o porta-voz transforma em trovão", "um tanto de touro e um tanto de criança”, "cara que parece ter sido feita pelo mar, beijada pelos ventos durante quarenta anos, ar de tempestade na fronte, carnação de rocha em pleno mar" (Hugo, 1866, p.54-55). Sobre outro marinheiro, Rantaine:

As suas narinas eram antes ventas de animal. Tinha no canto dos olhos uma encruzilhada de rugas onde toda sorte de pensamentos obscuros davam entrevista. [...] Assemelhavam-se as tais rugas a uma garra de abutre (Hugo, 1866, p.65).

Na descrição que Victor Hugo faz dos marinheiros, especialmente, há invariavelmente elementos de animal no humano. Mas esta transposição de limites que parece potencializar seu fôlego inventivo não diz respeito exclusivamente aos homens do mar: a apresentação da jovem Déruchette, por exemplo, remete-a a um devir-pássaro (Hugo, 1866, p.59). Para Claude Millet (2002), a personagem é propriamente a "mulher-pássaro".

As hibridaçóes entre o animal e o humano e entre estes e a natureza são exploradas nas multiplicidades um tanto fantásticas que aparecem nas narrativas de viagens do marinheiro Lethierry, nas quais ele contava ter conhecido figuras como os "homens-tigre", em sua passagem pela África, e coletivos como o "povomorcego", em sua rota pelo Brasil ${ }^{13}$ (Hugo, 1866, p.79-80). Após o naufrágio do barco a vapor que se chocou contra um rochedo, o autor menciona que o lugar onde se passavam os acontecimentos, Saint-Sampson, tinha "um rumor de colmeia assustada". Na soleira da casa de Lethierry, concentrava-se "um formigueiro de homens e mulheres" (Hugo, 1971, p.193). Essas metáforas de multiplicidades são também adotadas quando o escritor trata da natureza como espaço exterior, a exemplo desta passagem: "Gilliatt só tinha à roda de si o rumor do vento e a multidão das ondas" (Hugo, 1866, p.264). Na medida em que vai narrando o enfrentamento entre Gilliatt e as forças da natureza, o autor desfila imagens impactantes em meio às quais não é possível mais apontar o que diferencia o humano do não-humano, já que ambos os elementos se assemelham e se confundem no que diz respeito a sua intencionalidade ou mesmo malignidade. Vejamos este trecho: "Pessoa terrível essa é o vento. O vento, isto é, a população de titãs que chamamos tufôes. [...] Invisíveis pássaros ferozes do infinito" (Hugo, 1866, p.298). E, na sequência: "A cova dos ventos é mais implacável que a cova dos leôes” (Hugo, 1866, p.299). Ventos são sempre multiplicidades em sua prosa: "Se existe o demônio Legião, esse demônio é o vento". Em suas construções, o vento é múltiplo, mas o mar é um, de forma que, numa tal composição, "toda tempestade é mista” (Hugo, 1866, p.302-303). Imagens do humano, do animal e da natureza se acoplam e se sucedem nas suas junçôes e conjugaçōes. Mais do que uma sucessão de devires, sugiro que tais combinaçóes são uma esplêndida criação resultante do devir-natureza experimentado pelo autor. Tal como mencionam Deleuze e Guattari (1992, p.228), para criar multiplicidades - para encontrar "esse povo que ainda não existe" - o escritor "torce a linguagem, fá-la vibrar, abraçaa, fende-a”. Novos universos poéticos nascem justamente destas torções, destas fendas abertas pela escrita e das intensidades surgidas nestas vibraçôes que alteram o sentido anterior.

Como dito antes, Hugo prefere a noção de transnatureza à de sobrenatureza. Segundo 
o dicionário Aurélio (1989), o prefixo "trans" está relacionado a "movimento para além de", "através de"; "posição para além de" ou dizendo respeito à "intensidade". No dicionário francês Le Petit Robert (2001), "trans" recebe o sentido de "atravessar", de "transpassar", marcando também a passagem, a mudança, contida nos termos "transição" e "transformação". O termo devir, em ambos os dicionários, remeterá à ideia de mudança, de transformação, à passagem de um estado a outro. Ou seja, na noçáo de transnatureza, ao invés de um estado permanente e estável, temos um eco deste movimento de passagem e de transformação. Tais observaçóes são importantes para que se explicite o fato de que tais noçóes, como as de fluxo, de movimento e de intensidade, tão caras ao pensamento romântico, permeiam a própria construção poética de Hugo.

Ainda que apareçam de forma fugidia, por vezes temos em Os trabalhadores do mar o lusco-fusco de uma ideia de natureza exterior ao homem e de uma natureza interior, uma essência, remetendo às noçôes adotadas por Roy Ellen (1996). Mas tais noçóes, sempre móveis e fluidas, alteram-se no trecho seguinte. $\mathrm{O}$ autor menciona explicitamente a separação entre homem e natureza nas seguintes passagens: "A tristeza se mistura à natureza ao redor dele" (Hugo, 1866, p.27); "Gilliat contemplava a $n a-$ tureza de modo singular" (Hugo, 1866, p.42). Nas descrições dos jardins que cercam as casas, há o detalhamento de outra forma de natureza:

A moça preferia antes de tudo a campânula, depois o cravo, depois a madressilva, depois o jasmim. A rosa estava em quinto lugar. Quanto aos lírios, olhava para eles, mas não os cheirava (Hugo, 1866, p. 94).

É significativo que essa natureza relativa ao mundo vegetal seja apresentada de forma sempre mais acolhedora, menos ambígua e amea- çadora do que a representada pelo mar, pelos ventos e por certos animais.

O recurso da personificação da natureza, do antropomorfismo e do animismo, importante em toda a prosa de Hugo, está presente em passagens como estas: "O mar, quase sem dobras, tinha a ameaça fria da tranquilidade. Parece que há conluio neste excesso de calma” (Hugo, 1866, p.171). Em muitos trechos é evidenciada a ameaça das águas:

O mar aparece como uma emboscada; invisível clarim troa para uma estranha guerra. Longas e furiosas lufadas abalam o horizonte; é terrível o vento (Hugo, 1866, p.99).

O autor explora a intimidade das forças elementares, lançando mão de um incansável desfile de metáforas, como quando registra, por exemplo, as "vozes do vento" e ensaia a tradução desta riqueza polifônica. Murray Schafer (2001, p.43) assinala, a propósito desta obra, que "o vento, como o mar, apresenta um infinito número de variaçôes vocálicas”. Ele afirma que o vento e o mar têm sons de amplo espectro, possibilitando a escuta de inúmeras vozes. Gaston Bachelard (1998), por sua vez, lembrava que a água possui suas vozes indiretas. "A natureza repercute ecos ontológicos. Os seres respondem-se imitando vozes elementares" (Bachelard, 1998, p. 199, 201). Segundo esse filósofo, de todos os elementos, a água é o mais fiel "espelho das vozes". A seu ver, os grandes movimentos do imaginário nasceriam perto dos objetos: "todos os corpos da natureza produzem gigantes e anóes, o rumor das ondas enche a imensidade do céu ou o interior de uma concha” (Bachelard, 1998, p.201). Como assinala Poirot-Delpech (2002, p.2), com sua sensibilidade para as origens aquáticas do imaginário, Bachelard explicou o antropomorfismo de Hugo pela necessidade de encontrar intenções humanas na tempestade, como uma espécie de desígnio do Criador. As- 
sim, na obra de Hugo, os fenômenos naturais se assemelham seja à força do vento, à cólera ou a uma punição de Deus. Como leitores de Hugo, sentimo-nos - como a imagem a seguir evoca - pequenos diante do gigantismo da natureza descrito pelo escritor.

Há uma escala, na vasta turvação das solidôes: temível crescendo; a brisa, a lufada, a borrasca, o temporal, a tormenta, a tempestade, a tromba: as sete cordas da lira do vento, as sete notas do abismo. [...] Os ventos correm, voam, abatem-se, expiram, revivem, pairam, assoviam, rugem, riem; frenéticos, lascivos, desvairados, tomam conta da vaga irascível. Têm harmonia esses berradores. Tornam sonoro todo o céu. Sopram nas nuvens como num metal, embocam o espaço e cantam no infinito, com todas as vozes amalgamadas dos clarins, buzinas e trombetas, uma espécie de tangeres prometeanos. Quem os ouve, ouve Pã. O que mais assusta é vê-los assim. Têm uma colossal alegria composta de sombra. [...] Sáo os donos das matilhas. Divertem-se. Fazem ladrar as ondas, que são seus cães, contra as rochas. Combinam e desunem as nuvens. Amassam, como se tivessem milhões de mãos, a flexibilidade da água imensa (Victor Hugo, 1866, p. 300-301).

Tais elementos nos remetem a alguns dos aspectos analisados por Corbin (1989) acerca das diversas visões do mar nos séculos XVIII e XIX, que partem de uma interpretação bíblica do oceano primordial, caótico, abissal, incompreensível e demoníaco. Entre as várias imagens dominantes, o mar figura como "recipiente abissal dos restos do Dilúvio". A interpretação da Bíblia, particularmente do Gênese, dos Salmos e do Livro de Jó, marca essa representação do mar. No imaginário coletivo está o grande abismo, lugar de mistérios insondáveis, massa líquida sem pontos de referência, imagem do infinito. Tratase de um "reino do inacabado, vibrante e vago prolongamento do caos", que simboliza a desor- dem anterior à civilização. "Esse oceano irascível inspira profunda repulsa, pois a época clássica parece ignorar a tentação do retorno ao ventre criador, o desejo de absorção que atormentará os românticos" (Corbin, 1989, p.11-14).

No entanto, autores românticos como Hugo vão lançar mão justamente do estoque de imagens sobre o mar produzido pela época clássica. Em Os trabalhadores do mar, serve-se desse imaginário coletivo, alimentado com figuras de monstros que habitam nas profundezas, que provocam o horror do contato viscoso dessas criaturas de pesadelo, que vivem em cavernas tenebrosas. "Na tempestade, o navegador vê a mão do Diabo", assinalava Corbin. Essa ideia do oceano como avesso desordenado do mundo, morada dos monstros, agitado por poderes demoníacos, era justamente uma das figuras da desrazão (Corbin, 1989, p.17-18). Em Os trabalhadores do mar são numerosas as passagens que descrevem a tempestade e desenham o mar como essa substância caótica, como abismo povoado de monstros. São justamente as provas que Gilliatt precisa enfrentar na sua aventura heroica. Entre as imagens construídas por Hugo que se aproximam deste imaginário clássico, destaco a seguinte: "Ali [no mar] há antros, cavas, cavernas, cruzamentos de ruas tenebrosas. Pululam espécies monstruosas, devoram-se". O autor menciona formas medonhas, "feitas para não serem vistas por olhos humanos", que andam vivas naquela obscuridade, além de goelas, antenas, tentáculos, bocas abertas, garras e unhas que se misturam na profusão de terríveis criaturas (Hugo, 1866, p.158).

Pode-se considerar que é menos frequente no romance de Hugo a dimensão de uma natureza remetendo a uma essência humana. Há uma ou outra referência, por exemplo, quando o autor apresenta Mess Lethierry, um velho trabalhador do mar: "O fundo de sua natureza era o marinheiro. A água lhe pertencia. $\mathrm{O}$ oceano era a sua pátria" (Hugo, 1866, p.50). De outro modo, ao desvelar o que se passa no interior do 
personagem Clubin, após o navio que comandava ter-se chocado com o rochedo, Hugo procede a uma analogia entre uma natureza interna e outra externa, lançando máo de expressóes que conferem um caráter animalesco aos sentimentos do personagem, agora descoberto pelo leitor como um vilāo: "O foro íntimo, como a natureza externa, tem a sua tensão elástica”. $\mathrm{O}$ autor sugere que "uma ideia é um meteoro". Assim,

no momento do triunfo, entreabrem-se as meditaçóes acumuladas, que o preparam, e jorra uma faísca; ter em si uma garra do mal, e sentir nela uma presa, ventura é esta que tem a sua irradiação [...] (Hugo, 1866, p. 179).

A imagem é completada pela descrição de certas "felicidades ferozes" (Hugo, 1866, p. 180). No capítulo em que examina o caráter de Clubin, Hugo adota o título: "Alumia-se o interior de um abismo" (Hugo, 1866, p. 179), remetendo a um dos seus jogos de linguagem. Um dos já mencionados é o da personificação da natureza. Outro é o uso de imagens do exterior - aqui, mais exatamente do abismo - para evocar a face oculta e ambígua do personagem: "Há cavernas no hipócrita ou, antes, o hipócrita é uma caverna. Quando Clubin ficou só, abriu-se-lhe o antro" (Hugo, 1866, p.182). Uma indicação de que o íntimo humano mimetiza-se com a natureza exterior está no trecho em que Hugo descreve o jovem sacerdote que acompanha o velho padre na visita a Lethierry, ocasião em que vão oferecer-lhe conforto pelo naufrágio da embarcação. O autor define-o assim: "O mancebo tinha a gravidade da natureza” (Hugo, 1866, p. 204).

A dimensão do secreto e do misterioso é amplamente explorada por Victor Hugo, que narra a existência de pelo menos duas casas mal-assombradas no povoado. É onde reside todo o estigma e toda a suspeita que paira sobre o pescador Gilliatt: feiticeiro, filho do diabo, marcou. Um elemento supostamente relacionado ao sobrenatural é a embarcação a vapor, a Durande, apelidada pelos temerosos que vêem essa fusão de fogo e água como uma ofensa a Deus - de Devil-boat, o navio diabo ${ }^{14}$. $\mathrm{O}$ autor diz que pareciam chifres do diabo os cornos dos bois que o barco a vapor transportava. Explica que cem anos (1707-1807) separam o barco de Papin ${ }^{15}$ do primeiro navio de Fulton. "A Galeota de Lethierry era decerto um progresso sobre aqueles dois esboços, mas era esboço também” (Hugo, 1866, p.66-69). Hugo desenvolve uma engenhosa explicação sobre o maquinismo dos elementos:

O mar e o vento formam compostos de forças. O navio é um composto de máquinas. As forças são máquinas infinitas, as máquinas são forças limitadas. Entre os dois organismos, um inesgotável, outro inteligente, trava-se o combate que se chama navegação. [...] Uma vontade no organismo faz contrapeso ao infinito. Também o infinito encerra um organismo. [...] Os elementos sabem o que fazem e aonde vão. Não há força cega. Cabe ao homem espreitar as forças e descobrir-lhes o itinerário. Enquanto se não descobre a lei, prossegue a luta, e nessa luta a navegação a vapor [...] (Hugo, 1866, p.163).

Há uma luta da embarcação, da inteligência, da tecnologia, com a natureza, e um outro combate entre o homem e a natureza. Conforme Hugo,

a navegação a vapor é uma espécie de vitória perpétua que o gênio humano vai ganhando todas as horas do dia em todos os pontos do mar. A navegação a vapor é admirável porque disciplina o navio. Diminui a obediência ao vento e aumenta a obediência ao homem (Hugo, 1971, p.163).

Num arroubo de entusiasmo pela ciência, Hugo afirma que o vapor está ao lado do homem na sua luta com a natureza. Pode-se dizer que o elemento fogo, que produz o vapor, com a quei- 
ma do carvão, associa-se ao homem na sua batalha contra os elementos ar e água, que constitui a navegação. A propósito desta relação, Myriam Roman (2000, p. 78, 84) afirma que a noção de progresso em Hugo (que difere da visão positivista) está ligada à domesticação das forças da natureza pelo homem e, especificamente neste romance, relaciona-se à introdução do barco a vapor nas ilhas anglo-normandas. Hugo vê benefícios no progresso, mas não ignora que este também é gerador de catástrofes, expondo frequentemente os operários ao sacrifício, como no caso de Gilliatt.

No romance, o enfrentamento entre homem e natureza é encarnado por Gilliatt na sua tarefa heroica de resgatar a máquina da Durande dos rochedos, onde foi jogada pela tempestade. Quando o protagonista chega ao local, encontra estes vestígios: "Nada mais altivo e arrogante como tudo aquilo; o navio vencido, o abismo vitorioso. Os dois rochedos, ainda gotejantes da tempestade da véspera, pareciam dois combatentes em suor [...]”. Essa descrição empurra a imaginação em direção a cenas de um combate.

Os flancos escarpados tinham reflexos de armaduras. Pareciam encetar de novo a luta. Compreendia-se que elas nasciam de montanhas submarinas. Havia em tudo aquilo uma espécie de onipotência trágica. [...] Os dois rochedos, levantando acima das ondas o cadáver da Durande, tinham um ar de triunfo. Dissera-se dois braços saindo do golfão, e mostrando às tempestades o cadáver daquele navio (Hugo, 1866, p.218).

$\mathrm{Na}$ personificação da natureza, os rochedos ganham braços humanos e assumem sentimentos na celebração do "triunfo". O autor vai mais longe nesta imagem:

Tudo eram vestígios de raiva. As torçóes estranhas de certos ferros indicavam a ação impetuosa dos ventos. [...] Nenhum animal estrangula uma pedra como o ar. A água regurgita das gar- ras. O vento morde, o mar devora, a vaga é um queixo. É um socar e um esmigalhar ao mesmo tempo. O oceano tem um golpe igual à pata do leão (Hugo, 1866, p. 223).

O escritor menciona a "malignidade" e a "colaboração secreta dos elementos". Depois de narrar naufrágios como o que ocorreu em 1864, numa ilha nas costas do Malabar, Hugo ressalta que, na Europa, "onde parece que a $\mathrm{Na}$ tureza sente-se constrangida em respeito à civilização" tais acontecimentos são raros (Hugo, 1866, p.230). Tal luta, portanto, é aquela entre a natureza e a cultura, mas em sua narrativa trata-se de uma batalha sempre atravessada por múltiplos entrecruzamentos.

No combate travado por Gilliatt, a tempestade cede depois de ter atingido o paroxismo e de ter exaurido as forças do protagonista. Hugo descreve:

Há nos temporais um momento insensato; é para o céu uma espécie de sangue que sobe à cabeça. [...] O abismo já não sabe o que faz. Fulmina às apalpadelas. Nada mais horrendo. [...] A tempestade tem um plano misterioso; mas nesse instante, perde-o (Hugo, 1866, p.321).

A sabedoria e a destreza do herói fazem a sua vitória. Ele aprende a usar o obstáculo para construir o triunfo com invençóes que aproveitam o ar, a água e o fogo. Torna-se assim "senhor dos elementos” (Hugo, 1866, p.247). Essa sabedoria surge da intuição da verdade, "mais clara às vezes num espírito simples que num espírito complicado". Ignorar convida a tentar. "A ignorância é um devaneio e o devaneio curioso é uma força”. Como foi sendo evidenciado, o protagonista, como seu criador, é um "vidente da natureza" (Hugo, 1866, p.266). Tendo vencido a tempestade, Gilliatt sentiu "essa imemorial necessidade de insultar o inimigo, que remonta aos heróis de Homero" (Hugo, 1866, p.323). 
Sua batalha final dá-se com um monstro que habita as cavernas tenebrosas do mar, a pievre: "Este monstro é aquele que os marinheiros chamam polvo, que a ciência chama cefalópode e que a lenda chama kraken" (Hugo, 1866, p.397). Agarrado por esta “máquina pneumática que mata” por meio da aspiração, Gilliatt tinha presos em seu corpo 250 sugadores. O autor adverte que há apenas uma maneira de vencer o polvo ${ }^{16}$, que só é vulnerável na cabeça. A faca foi o recurso de Gilliatt: ele atingiu a figura monstruosa num golpe preciso, certeiro. O herói do romance, na sua luta contra os elementos, triunfa sobre a tempestade e o monstro marinho. Capaz de renúncia, perde, no entanto, a possibilidade de amor ${ }^{17}$ - permitindo o fecho trágico da aventura com a sua submersão nas águas. Em tais desdobramentos, reencontramos um signo derradeiro da literatura romântica: a fusão do homem com a natureza, uma interpenetração tanto física quanto simbólica.

\section{Consideraçóes finais: a saga de um herói "banido"}

Como retrato de sua própria condição de exilado - e exaltação da dignidade dos membros de classes populares -, Victor Hugo forja nesta obra um herói que, socialmente, é visto com desconfiança e desprezo. Gilliatt, cuja vida foi concebida e escrita durante o exílio do escritor, é ele mesmo um permanente estrangeiro em sua terra, um estranho em sua aldeia. Filho de mãe estrangeira (talvez inglesa ou francesa), o rapaz habitava uma casa que teria sido mal-assombra$\mathrm{da}$, na qual, segundo as crenças das populaçóes campesinas e marítimas, "o diabo aparece durante a noite”. Mas o fato de que a casa já não fosse mal-assombrada não reduz as desconfianças, pois

é sabido que, quando um feiticeiro vem habitar uma casa visitada pelo diabo, este, julgando-a bem guardada, tem a delicadeza de não voltar, salvo o caso de ser chamado (Hugo, 1971, p.21).

Gilliatt tinha assim fama de feiticeiro. Acreditava-se também que pudesse ser um marcou, a maldição que carrega o sétimo filho homem, que corresponde também ao lobisomen, esse ser ambíguo que se transforma tanto em lobo como em homem. Como menciona Hugo, testemunhas afirmavam ter-lhe visto a marca corporal que identifica um marcou: a flor de lis impressa no corpo. Para outros, o rapaz seria o próprio filho do diabo. Em todas as atribuiçôes, Gilliatt é sempre remetido à figura do Outro, àquele cuja natureza se desconhece, o que está no limiar entre o humano e o não humano.

Hugo vai atestar que, na verdade, Gilliatt "era apenas um pobre homem sabendo ler e escrever". Como diz seu criador, talvez ele estivesse no limite que separa o sonhador do pensador. Quando perguntado sobre sua profissão, o rapaz respondia que era "um pescador, quando havia peixe". Como Hugo, Gilliatt mantinha uma relação singular com a natureza e alimentava suas próprias convicçóes: acreditava, por exemplo, que o ar fosse habitado por transparências vivas. Pois se o mar estava cheio de criaturas, por que motivo a atmosfera estaria vazia? Esse homem, que vivia "banido" socialmente como o próprio Hugo se considerava desde o desterro -, encontra no heroísmo e no sacrifício sua possibilidade de redenção, mas o faz apenas porque um desafio tocou o âmago de sua sensibilidade amorosa, mais refinada nele - visto como um bruto - do que naqueles que o cercavam. Partindo de Yves Gohin, Claude Millet (2002, p.14) afirma que este romance retoma o "mito universal do herói vencedor do monstro", articulando iniciação e procura amorosa, de forma que as proezas, como a luta contra o monstro, são provas para merecer a mulher amada. $\mathrm{O}$ mito, surgido em contos populares, foi retomado abundantemente pela literatura. 
Tal como Émile Zola - que alguns estudiosos consideram seu herdeiro ${ }^{18}$ e que realizou uma etnografia minuciosa da sociedade francesa antes de escrever a saga dos Rougon-Macquart, em cujas obras encontra-se Germinal-, Victor Hugo parece conferir tamanha intensidade narrativa ao universo de Os trabalhadores do mar porque tal empreitada de concepção e de escrita foi precedida e alimentada por minuciosa observação e estudo dos hábitos, das práticas e das crenças de moradores da ilha de Guernesey, durante 15 anos de degredo. No caso de Zola, fala-se da dupla condição de "romancista e etnógrafo" porque esses estudos prévios, que viriam a ser o "material genético" de sua obra, foram publicados postumamente como Carnets d'enquêtes ${ }^{19}$. Nos escritos de Hugo, não são tão explícitas as pistas etnográficas, embora o autor tenha deixado igualmente uma vasta herança de diários e notas, reunidos, por exemplo, em Choses vues 1830-1885 (dois volumes publicados em 1887 e 1900), e nos Carnets intimes (Guillemin, 1953), além de outras formas de expressão, como os desenhos. É emblemático o fato de Os trabalhadores do mar ser o único romance do autor que porta uma dedicatória ${ }^{20}$. Nesta, o escritor presta homenagem aos habitantes da ilha de seu longo exílio:

Dedico este livro ao rochedo de hospitalidade e de liberdade, a este canto da velha Normandia onde vive o nobre e pequeno povo do mar, à ilha de Guernesey, severa e branda, meu atual asilo, meu provável túmulo (Hugo, 1971, p.9).

Pode-se dizer, como Focillon (2001), que se trata mesmo "de um livro escrito pela mão de um marinheiro, carpinteiro e ferreiro, que se apodera da forma do objeto e o modela, moldando-se também a ele", um pouco como nós etnógrafos ensaiamos fazer - ainda que geralmente em limites mais modestos - pelo mergulho no mundo vivido de nossos interlocutores ou pela imersão no mundo da literatura.

\section{Between the sea and the cliff: an anthro- pological analysis of the notion of Nature in Victor Hugo's Workers of the Sea}

abstract This article analyzes the universe of the French writer Victor Hugo and investigates how its conceptions of nature - marked by the romantic values of the $19^{\text {th }}$ century - gain body and density in the novel The workers of the sea (1866). This article focuses on the epic of man against Nature and follows the life path of Gilliatt: a fisherman who not only embodies the values of his creator, but also stands for a symbol of the tragedy of individuals from the working class, who are considered worthy only for their sacrifice and heroism. Adopted as a metaphor in his narrative, the mixture between different elements, between human beings and non-human beings in the flow of images created by Hugo indicates a kind of "becoming" (devenir) (Deleuze; Guattari, 1997), in which the intensities that compose the author's imaginary generate surprising multiplicities.

keywords Anthropology. Literature. Victor Hugo. Workers of the sea. Nature.

\section{Notas}

1 Uma primeira versão deste texto foi apresentada como trabalho final no curso "A 'natureza' na Cultura Ocidental Moderna, características cosmológicas e implicaçóes epistemológicas", ministrado por Luiz Fernando Dias Duarte, Ana Maria Lima Daou e Jayme M. Aranha Filho, no PPGAS-MN-UFRJ, em 2005/1.

2 Termo utilizado num poema de Louis Aragon, em 1940: “enfer-les-mines". Ver Cooper-Richet, 2002, p. 58.

3 Estou considerando Corbin (1989) sobre a invenção do desejo da beira-mar e o que escreveu Nery sobre a "observação e uso da natureza como elemento de consumo sensorial (estação de águas, praia, estação de esqui), a partir da ideia de 'paisagem' como estímulo sentimental” (Nery apud. Duarte, 1999, p.28).

4 Espécie de reação ao iluminismo, o romantismo exprimiu uma nova sensibilidade, compreendendo a revalorização da natureza. O movimento surgiu inicialmente na Inglaterra e na Alemanha, florescendo na França a partir de 1827. Como analisou Duarte (2004), en- 
quanto o modelo iluminista baseava-se no racionalismo, no empiricismo, no mecanicismo, no objetivismo, na homogeneidade e no materialismo, no pensamento romântico sobressaíam as seguintes dimensóes: totalidade, diferença, fluxo, pulsão, experiência e compreensão (Duarte, 2004, p. 1-9). No caso francês, tratava-se, nos termos de Bénichou (1988), de "um momento de espera, de ressurreição e de metamorfose após o maior cataclisma humano que a Europa conheceu”, ou seja, a Revolução Francesa de 1789.

5 Oúltimo dia de um condenado (1929) é a obra na qual Hugo expressou suas convicções sobre o tema.

6 Neste período, Hugo mantinha hábitos aristocráticos que não agradavam aos outros desterrados franceses vivendo modestamente na ilha. Seu envolvimento com o espiritismo também não era visto com bons olhos pelos vizinhos e conhecidos. Em uma versão, esta teria sido a causa de sua expulsão da ilha pelas autoridades locais. Em outra versão, a expulsão teria sido motivada pelo fato de ele ter defendido os redatores do jornal republicano L'Homme.

7 Da sua produção no exílio, podemos destacar: na ilha de Jersey, publicou História de um crime (1852a), Napoleão, o pequeno (1852b) e Os castigos (1853); no período em Guernesey, publicou As contemplaçôes (1856), A legenda dos séculos (1859), Os miseráveis (1862) e Os trabalhadores do mar (1866).

8 Hugo morreu em Paris, aos 83 anos, em 22 de maio de 1885. Antes ser sepultado no Panteão, lugar de honra destinado aos heróis nacionais, foi homenageado por dois milhóes de pessoas que acompanharam o cortejo.

9 É bom lembrar a forma como Pascal referia-se à natureza, como sendo este "universo mudo".

10 Deve-se considerar o processo pelo qual o homem deixou de fazer parte da natureza, estatuto mantido na Idade Média, para explorá-la e dominá-la no Renascimento. A este propósito, ver Robert Lenoble (1990, p. 256). O trabalho de Keith Thomas (1988) também nos fornece elementos sobre o fato de que, nos séculos XVI e XVII, "civilização humana” significava conquista da natureza, com a teologia da época fornecendo os alicerces morais para o predomínio do homem sobre a natureza (ver Thomas, 1988, p. 27-31).

11 Embora suscite um parentesco de ideias, a constituição dessa "cadeia" difere da analisada por Arthur Lovejoy (1993) e, secundariamente, por Stephen Jay Gould (1990, p.261), que a define assim: "Na grande cadeia do ser, cada organismo forma um elo definido dentro de uma sequência única, que vai da mais hu- milde ameba numa gota d'água a seres cada vez mais complexos", culminando com o ser humano.

12 Nos estudos sobre o romantismo, a questáo da paisagem mereceu inúmeras abordagens elucidativas. Destaco aqui um trecho de "A filosofia da paisagem", de Simmel (1996, p.17): "Para que nasça a paisagem, é preciso inegavelmente que a pulsação da vida, na percepçáo e no sentimento, seja arrancada à homonegeidade da natureza e que o produto especial assim criado, depois de transferido para uma camada inteiramente nova, se abra ainda à vida universal e acolha o ilimitado nos seus limites sem falhas". Outra contribuição significativa aparece na obra de Simon Schama (1996, p.17), na qual o autor considera a paisagem como sendo uma obra da mente, que se compóe tanto "de camadas de lembranças quanto de estratos de rochas". Ele mostra também como a paisagem nem sempre é lugar de prazer, podendo representar a "tragédia pública", como os campos de concentração nazistas. Na obra de Ricotta (2003) a respeito de Humboldt, a própria viagem geográfica constitui um estímulo que revitaliza a cultura subjetiva, na medida em que a linguagem poética estabelece um novo elo entre natureza e vida humana.

13 Na ficção tecida por Hugo, o marinheiro Lethierry passou pelo rio Arinos, afluente do Tocantins, no Centro-Oeste brasileiro, detalhes que revelam um razoável conhecimento geográfico do escritor sobre o país. Júnia Barreto (2002), num estudo sobre as relaçôes do poeta com o Brasil, observou que nos anos 1930, quando o etnólogo Claude Lévi-Strauss visitou a região, o local descrito por Hugo - onde haveria o "povo-morcego" que, segundo a narrativa do escritor, eram "homens que nascem com os cabelos brancos e os olhos vermelhos", que habitam os bosques e caçam durante a noite - era habitado pelos Nhambiquara. Neste romance, há outra passagem na qual Hugo faz referência ao Brasil: "No Rio de Janeiro, [Lethierry] viu as senhoras brasileiras colocarem nos cabelos pequenas bolsas de gaze contendo cada uma delas um vagalume, o que lhes fazia uma coifa de estrelas"(ver Hugo, 1971, p.79-80).

14 Leite Lopes (1978) oferece uma preciosa análise sobre o "vapor do diabo" em sua etnografia sobre o trabalho dos operários do açúcar.

15 Em Becquemont (1990) há a apresentação de um diálogo sobre a máquina a fogo e a máquina a vapor, entre Papin e Leibniz.

16 Ver a análise de Aranha Filho (1990, p.125) sobre o polvo e seus "tentáculos manipulativos". 
$17 \mathrm{Na}$ interpretação de Claude Millet (2002, p.13), Os trabalhadores do mar é um "romance de amor", que liga as trajetórias de Gilliatt, Déruchette e Ebenezer. A autora avalia que, entre o primeiro e o último capítulo, o romance percorre um trajeto que não é senão aquele de uma "tragédia amorosa".

18 Journet (1988, p.114) afirma que "o herdeiro mais direto de Victor Hugo bem que poderia ser Zola". Ele menciona que esse entendimento era compartilhado pelo zolista Guy Robert, ainda no final do século XIX, e por Gustave Lanson, para quem essa aproximação entre os dois escritores náo era senáo um elogio ambíguo.

19 Os estudos de Zola são considerados como "uma verdadeira contribuição à etnografia histórica da França”, como enuncia Henri Mitterand (2001), especialista em sua obra. Segundo Mitterand, depois de vinte anos de observações, Zola reuniu as três principais características da pesquisa etnográfica: o trabalho de campo, a observação de fenômenos particulares a grupos restritos, a análise e observação dos fenômenos observados para elaborar documentos descritivos e sínteses (ver Mitterand, 2001, p.13).

20 A este propósito, ver Roman (2002, p.1).

\section{Referências bibliográficas}

ARANHA FILHO, Jayme M. Inteligência extraterrestre e a evolução. As especulaçôes sobre a possibilidade de vida em outros planetas no meio científico moderno. Dissertação (Mestrado) - Programa de Pós-Graduação em Antropologia Social, Museu Nacional, Universidade Federal do Rio de Janeiro, Rio de Janeiro, 1990.

BACHELARD, Gaston. A água e os sonhos. Ensaio sobre a imaginação da matéria. São Paulo: Martins Fontes, 1998.

BAKHTIN, Mikhail. Estética da criação verbal. São Paulo: Martins Fontes, 1997.

BARRETO, Júnia. Victor Hugo e o Brasil: o que permanece do homem e do escritor no milênio da globalização. In: SIMPÓSIO INTERNACIONAL VICTOR HUGO, GÊNIO SEM FRONTEIRAS. Universidade Federal de Minas Gerais. Belo Horizonte: 2002. Disponível em: http://www.letras.ufmg.br/victorhugo/victorhugo paginas/victor frameset.htm. Acesso em: 10 set 2009.

BECQUEMONT, Daniel. La machine à feu: travail humain et forces de la nature. Correspondence entre Wilhelm Leibniz et Denis Papin. Gradhiva. Revue d'Histoire et d'Archives de l'Anthropologie. n.8, p.66-81, 1990.
BÉNICHOU, Paul. Les mages romantiques. Paris: Éditions Gallimard, 1988.

CHARLES, David. Hugo et la référence à l'actualité : l'exemple des Travailleurs de la mer. In: COLLOQUE ACTUALITÉS DE VICTOR HUGO, 2002, Vianden. Anais.... Vianden: Université du Havre, 2002. Disponível em: <http://groupugo.div.jussieu.fr/Groupugo/ doc/03-03-15Charles.pdf > Acesso em: 10 set. 2009.

Hugo, le travail et la misère. In: CONGRÈS DES SOCIETÉS HISTORIQUES ET SCIENTIFIQUES. 127 ème. 2005. CTHS. Actes du 127 ème Congrès des Societés Historiques et Scientifiques. Le travail et les hommes. Nancy, 2005. Disponível em: $<$ http://groupugo.div.jussieu.fr/Groupugo/Textes et documents/Charles le travail et la misere.pdf > Acesso em: 10 set. 2009.

CIOCCARI, Marta. Ecos do subterrâneo. Estudo antropológico do cotidiano e memória da comunidade de mineiros de carvão de Minas do Leão (RS). Dissertação (Mestrado) - Programa de Pós-Graduação em Antropologia Social, Universidade Federal do Rio Grande do Sul, Porto Alegre, 2004.

COOPER-RICHET, Diana. Le peuple de la nuit: mineurs et mines en France, XIX et XX siècles. Paris: Perrin, 2002.

CORBIN, Alain. O território do vazio. A praia e o imaginário ocidental. São Paulo: Ed. Schwartz, 1989.

DELEUZE, Gilles \& GUATTARI, Félix. O que é filosofia. Rio de Janeiro: Ed.34, 1992.

.Mil platôs. Capitalismo e esquizofrenia. V. 1. Rio de Janeiro: Ed.34, 1995.

. Mil platôs. Capitalismo e esquizofrenia. V. 4. Rio de Janeiro: Ed.34, 1997.

DESCOLA, Philippe. "Constructing natures: symbolic ecology and social practice”. In: DESCOLA, P.; PÁLSSON, G. (orgs.). Nature and Society. Anthropological perspectives. Londres: Routledge, 1996. p. 82-102.

DUARTE, Luiz Fernando Dias. A pulsão romântica e as ciências sociais no Ocidente. Rev. Bras. Ci. Soc. v.19, n. 55, p. 5-18, Jun 2004.

ELLEN, Roy F. The cognitive geometry of nature: a contextual approach. In: DESCOLA, P., PÁLSSON, G. (orgs). Nature and society. Anthropological perspectives. Londres: Routledge, 1996. p. 103-123.

FERREIRA, Aurélio Buarque de. Novo Dicionário Aurélio Século XXI da Língua Portuguesa. Rio de Janeiro: Nova Fronteira, 1989. 2128 p. Versão consultada on-line: Dicionário Aurélio Eletrônico, Século XXI, Versão 3,0. Novembro de 1999.

FOCILLON, Henri. Elogio da mão. In: A vida das formas. Lisboa: Ediçôes 70, 2001. p. 105-129. 
GOULD, Stephen Jay. O sorriso do flamingo. Reflexôes sobre história natural. São Paulo: Martins Fontes, 1990.

GUATTARI, Félix. As três ecologias. Campinas, SP: Papirus, 2004.GUILLEMIN, Henri. Carnets intimes de Victor Hugo, 1870-1871. Paris: Gallimard, 1953.

HUGO, Victor. História de um crime. In: . Obras

Completas, v. 19, 20. São Paulo: Editora das Américas, [1852a] 1957.

. Napoleão, o pequeno. In: . Obras Completas,

v. 18. Sáo Paulo: Editora das Américas, [1852b] 1957. . Les châtiments. Paris: Nelson Éditeur, [1853] 1920. . As contemplaçóes. In: Obras Completas,

v. 42. São Paulo: Editora das Américas, [1856] 1957. - A lenda dos séculos. In: Obras Completas,

v. 42. São Paulo: Editora das Américas, [1859] 1957. . Os miseráveis. São Paulo: Cosac Naify, [1862] 2002. . Os trabalhadores do mar. Trad. Machado de Assis.

São Paulo: Abril Cultural, [1866] 1971.

. [1929]. O último dia de um condenado. São Pau-

lo: Editora Estação Liberdade, 2002.

. Choses Vues: 1849-1869. Paris: Gallimard, 1972.

JOURNET, René. Victor Hugo et la métamorphose du roman. Romantismo, v. 18, n. 60, p.109-114, 1988.

LEITE LOPES, José Sérgio. O vapor do diabo. O trabalho dos operários de açúcar. Rio de Janeiro: Paz e Terra, 1978.

LENOBLE, Robert. História da ideia de natureza. Lisboa: Ediçôes 70, 1990.

LE PETIT ROBERT. Le CD-ROM du Petit Robert, Version électronique du Nouveau Petit Robert dictionnaire alphabétique et analogique de la langue française. Version 2.1. VUEF: Paris, 2001.

LOVEJOY, Arthur. The great chain of being. A study of the history of an idea. Local: Harvard University Press, 1993.

LUCAS, Philippe. La religion de la vie cotidienne. Paris: PUF, 1981.

MILLET, Claude. Les travailleurs de la mer de Victor Hugo: un roman d'amour. Romantisme, v. 32, n. 115, p.13-23, 2002.

MITTERAND, Henri. “Avant-propos”. In: ZOLA, E. Carnets d'ênquetes. Une ethnographie inédite de la France. Paris: Plon; Terre Humaine, 2001, p. 9-19.
POIROT-DELPECH, Bertrand. Victor Hugo et la mer. Célébration du bicentenaire de la naissance de Victor Hugo. Discours prononcé à l'Academie Française le 28 fév. 2002, Paris. Disponível em: <http://www.academie-francaise.fr/Immortels/discours divers/poirotdelpech 2002.html> Acesso em: 22 mar. 2009.

RICOTTA, Lúcia. Natureza, ciência e estética em Alexander von Humbold. Rio de Janeiro: MAUAD, 2003.

ROMAN, Myriam. Ce cri que nous jetons souvent: le Progrès selon Hugo. Romantisme, v.30, n. 108, p.7590, 2000.

Les îles anglo-normandes : insularité et communauté dans Les Travailleurs de la Mer de Victor Hugo. In: COLLOQUE FRANCO-HÉLLÉNIQUE D’ATHÈNES, 2002, Local. Disponível em: <http:// groupugo.div.jussieu.fr/Groupugo/Textes et documents/Roman Insularité et communauté.pdf> Acesso em: 10 set. 2009.

SCHAFER, R. Murray. $A$ afinação do mundo. São Paulo: Unesp, 2001.

SCHAMA, Simon. Paisagem e memória. São Paulo: Companhia das Letras, 1996.

SIMMEL, Georg. . A filosofia da paisagem. Política e Trabalho, n.12, p.15-24, 1996.

El individu y la libertad. Ensayos de crítica de la cultura. Barcelona: Editora Península, 1998. 284 p.

SIMONIN, Louis La vie souterraine. Les mines et les mineurs. Paris: Champ Vallon, [1867] 1982.

THOMAS, Keith. O homem e o mundo natural. São Paulo: Companhia das Letras, 1988.

ZOLA, Émile Germinal. São Paulo: Abril Cultural, [1885] 1979.

Carnets d'enquêtes. Une ethnographie inédite de la France. Présentation d'Henri Mitterand. Paris: Plon, Terre Humaine, 2001. 686 p.

\section{Agradecimentos}

Agradeço a José Sergio Leite Lopes e a Luiz Fernando Dias Duarte pelo precioso estímulo e por seus comentários a versóes iniciais deste texto.

\section{autora Marta Cioccari}

Doutoranda em Antropologia Social/MN-UFRJ

Recebido em 22/03/2009

Aceito para publicação em 06/11/2009

cadernos de campo, São Paulo, n. 18, p. 29-46, 2009 